\title{
A tribute to Gérard Breton (1944-2020)
}

\author{
Homenaje a Gérard Breton (1944-2020)
}

Danièle Guinot ${ }^{1}$, Alessandro Garassino ${ }^{2}$, FranciscoJ. Vega ${ }^{3, *}$

\author{
${ }^{1}$ Muséum National d'Histoire Naturelle. 57 \\ Rue Cuvier, 75005 Paris, France. \\ ${ }^{2}$ Department of Earth and Biological Sciences, \\ Loma Linda University, Loma Linda, Califor- \\ nia 92350, USA. \\ ${ }^{3}$ Instituto de Geología, Universidad Nacional \\ Autónoma de México, Ciudad Universitaria, \\ Coyoacán, CDMX, 04510, Mexico. \\ * Corresponding author: (F. J. Vega) \\ vegver@unam.mx
}

\section{PREFACE}

Gérard Breton, born in Le Havre on 20 April 1944, brilliant scientist of international stature, associate paleontologist at Géosciences Rennes for many years, passed away on 3 April 2020. This special issue is dedicated to him as a tribute to his work and mastery, with a compilation of papers on some topics related to his ample research experience.

A student at the Lycée François 1er, he continued his scientific studies in Earth Sciences at the University of Caen. In 1965 he became a certified teacher of natural sciences at the Lycée Porte-Océane. In 1968 he obtained the most prestigious French professional qualification for teachers in Natural Sciences in France, called 'agrégation' (at 24 years old, he was one of the youngest in France), then he defended in October 1990 a doctoral dissertation - Sciences, on the evolution of fossil Asterids.

After having cooperated in Algeria (VSNA $=$ Volontaires du Service National Actif) at the Faculty of Sciences of Oran, he settled in Le Havre as a science teacher at the Porte-Océane high school. In 1973, he was appointed full-time director of the Muséum du Havre, in support of the curator André Maury. As director for 32 years of the Museum of Natural History of Le Havre (1973-2005), he worked in multiple fields. More specifically, he provided the Museum with a taxidermy laboratory, developed a branch of geology-palaeontology equipped with a laboratory, a national highlight for castings, polishing, and thin plates, had an experimental hive implanted under glass and supervised by a beekeeper. Thanks to him, the remarkable Charles-Alexandre Lesueur heritage fund was placed under the responsibility of a scientist, thus ensuring its influence in Europe, America, and Australia. The staff of the Museum went from 4 to 22 curators from 1973 to 1984, and it was 19 in 2005. Through its intense museological activity, the Museum of Le Havre enjoyed a national and international scientific influence.

At the same time, Gérard carried out an important research activity in geology and palaeontology. He regularly attended the Geological Society of Normandy and the Friends of the Museum of Le Havre, of which he became general secretary (1973-2004).

Ph.D. in paleontology, he was internationally recognized as one of the few experts in the evolution and diversity of asterids (starfishes). He actively participated in scientific dissemination and led many geological excavations from 1972.
Peer Reviewing under the responsibility of Universidad Nacional Autónoma de México.

This is an open access article under the CC BY-NC-SA license(https://creativecommons.org/licenses/by-nc-sa/4.0/) 
Retired in June 2005, Gérard Breton founded "Port Vivant", of which he was the scientific advisor for the research on the biodiversity of harbor basins. He studied the faunas of the Le Havre basins extending and comparing them to those of a freshwater harbor: Rouen. He was also active on the field and an excellent diver.

In 1976 he became enthused with diving when his divers from the Havre firefighters brought him from the harbor an ascidian never before found in the Channel: he admitted to having wanted to learn to dive to personally observe this ascidian in its ecosystem. He maintained a passion for underwater exploration. He developed scientific work around "organic dives" in the basins of the Le Havre harbor, which went hand in hand with diffusion work on marine biology among divers and a wider audience. In 1995, Gérard participated to the creation of the Plongeurs Naturalistes de Tatihou, which later became the Plongeurs Naturalistes de Normandie. (PNN), with some 300 divers. Gérard was therefore known throughout the world for his activities as a diver and his invaluable expertise for the scientific validation of his missions as a researcher and naturalist photographer (photos and videos). He led several summer's courses in marine biology in Cerbère, in southern France, near the Spanish border.
A militant naturalist, from the Republican school, he still had many research projects in geology and marine biology in particular.

A palaeontologist of great curiosity and encyclopedic knowledge, author of numerous scientific publications, Gérard was one of those old-fashioned naturalists, interested in everything related to Geology and Paleontology, from his initial subject of competence, the Echinoderms, to amber organisms and dinosaur eggs, all the way to the many living and palaeontological oddities and rarities that he encountered. Gérard was always helpful, sparing his time to help, always with kindness, modesty, and an inimitable sense of humor. His dedication as an associate was flawless. His numerous lectures attracted a passionate audience.

He was a "jack-of-all-trades" naturalist who had a constant interest in the most complex and least publicized areas of palaeontology; thus, his work in microichnology (micro-traces of fossils of biological origin), developed over the past 10 years, has been published in leading scientific journals.

Gérard Breton was an erudite and brilliant man, passionate and fascinating, who left wonderful memories to all those who had the good fortune to cross his path.

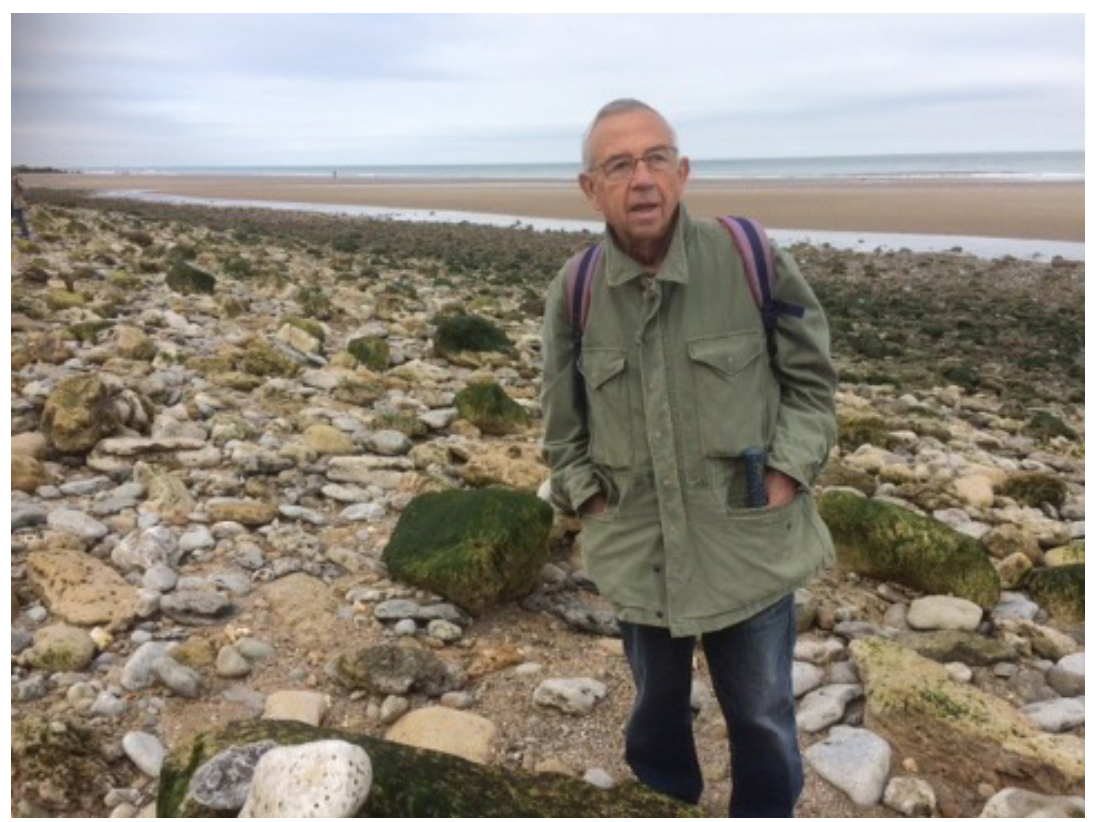

Figure 1 Gérard Breton, paleontological site of the Vaches Noires near Villers-sur-Mer, Calvados, Normandy, France. Picture: Antonio De Angeli. 